\title{
Impacts of Consumerism in India: Some Religious-Ethical Responses
}

\author{
Morris Antonysamy
}

\begin{abstract}
:
Tulisan ini mencoba untuk memahami beberapa dampak konsumerisme di India dengan cara melihat fenomena konsumerisme dari tiga sudut pandang, yaitu ideologi, cara hidup, serta gerakan sosial. Analisis ini membantu untuk memahami akar beberapa persoalan dari dunia dewasa ini, seperti kemiskinan dan korupsi. Untuk menanggapi budaya konsumtif dari sudut pandang etis, diambil inspirasi-inspirasi yang berasal dari agama Buddha, Hindu dan Kristen. Artikel ini ditutup dengan sebuah tantangan bagaimana kita dapat menjembatani dikotomi antara cita-cita agama dan absennya cita-cita tersebut dalam struktur sosial-ekonomi-politik suatu negara.
\end{abstract}

\section{Key Words:}

Consumerism, India, culture, consumption, religious, life, market.

\section{INTRODUCTION}

The English word "consume" comes from the French consumer which is rooted in the Latin consumere, meaning to devour, waste, exhaust. Its English usage (consume, consumer, consumption) was negative, with consumption being popularly employed to describe tuberculosis. During the 18th century the word began to be used by political economists without the negative connotation: a consumer was distinguished from a producer, and consumption became the counterpart to production ${ }^{1}$. In the mid20th century the word became commonly accepted as a replacement for customer as the buyer or purchaser of goods. Raymond Williams sees this as significant since "customer had always implied some degree of regular and continuing relationship to a supplier, whereas consumer indicates the more abstract figure in a more abstract market $^{2}$."
When we look at the evolution of market economy, modern industrial development indicates a drastic change in economic attitudes, i.e. production and sales. The separation between produces and consumers created the necessity of an inter-player, market. In the Indian subcontinent, the mode of industrial development has been operational both in pre and post independent India. However, the phenomenon of consumerism plays a more influential role in the lives of people ever since the new liberal economic policies have been introduced (1994). Consumerism has become more visible and tangible in the era of neo-liberalization and economic globalization. The arrival of special economic zones, the development of IT parks, the acceleration of industrialization and mechanization, coupled with liberalization of market and privatization of public sectors have considerably affected consumers' survival 
and attitudes. Against this background, this paper articulates certain impacts of consumerism in India. It approaches consumerism from three angles, i.e. ideology, way of life, social movement. Finally it proposes some ethical responses from three Asian religious traditions, i.e. Buddhism, Hinduism and Christianity. They offer visions for a counterculture to consumerism.

\section{CONSUMERISM AS AN IDEOLOGY}

According to Oxford Advanced Learner's Dictionary, an ideology is "a set of ideas that an economic and political system is based on." It shapes our perceptions and conceptions. Consumerism as an ideology, argues Kenneth R. Himes, "is a way of talking about a market mentality that defends individual's freedom of choice and entrepreneurship criticizing economic models like communism, socialism or other approaches that interfere rational agents making decision in minimally regulated free markets."3

In Development as Freedom Amartya Sen points out a conversation between a wife (Maitreyee) and her husband (Yajnavalkya), which is found in the Brihadaranyaka Upanishad dating $8^{\text {th }}$ Century CE. In this conversation Maitreyee wonders whether it could be the case that if "the whole earth, full of wealth" were to belong just to her, she could achieve immortality through it. "No," responds Yajnavalkya, "like the life of rich people will be your life. But there is no hope of immortality by wealth." Maitreyee remarks, "What should I do with that by which I do not become immortal?"4 From this conversation, Sen moves on to the contemporary scenario. Leaving aside the question of immortal life, Sen asks whether people are able to achieve in this world what they strive for ${ }^{5}$. In other words, how far our material possessions satisfy our reasonable desire for happiness, relaxation and peacefulness? This could be the key question as to evaluate the promises of consumerism which equates prosperity with happiness.

\section{Markets Dictate}

Markets have devised an indirect mechanism of forcing consumers to buy more. Freebies, promotional packs and special offers are marketing techniques that create a compulsion among people to buy something which may not be needed at that moment. The more one consumes, the more one receives "extras" from the market and this incentive makes one consume still more in return. Thus a cycle of consumption and reward goes nonstop. The unquenchable desire for "more" and "more" leaves one eternally unhappy and unsatisfied.

Moreover, one's needs are determined by market. That is one's wants are created. Most of the advertisements directly make value judgments about the behaviour and character of consumers. "If you are an intelligent/clever man/woman you should buy..." seems to be the jargon of almost all ads. These ads target the psychological vacuum in people, who would seek recognition and approval from outside. The advertizing agents are mostly film and sport stars who naturally enjoy some reputation by virtue of their profession. This reputation becomes a great asset to media and ads. People hardly disbelieve or challenge the quality of a product when it is advocated by such popular figures. While these big stars make huge amount of money for appearing just for a few minutes or seconds, the advertized products make tremendous profit on a very large scale. What needs to be critically looked at is the fact that media and ads tremendously influence our moral choice, i.e. what and how much we should consume?

\section{Consumerism and Politics}

Consumerism influences political decisions. Different government schemes and policies reflect consumerist interests. Recently the High Court of Tamil Nadu made wearing of helmets compulsory while driving two wheelers. Within two to three days the entire stock was sold out. And after three days the state government announced that it is no more mandatory to wear helmets. In order to understand the real cause 
for this sudden shift, we should investigate the interplay between economics and politics.

In a democratic polity, public elections decide the political authority of the state. In such electoral politics, political parties are funded by business groups. And governments formed by these parties are obliged to favour such groups. This would be reflected in their policies and laws. For example, the recent land bill is pushed through with all might by the union government despite strong opposition from farmers nationwide and from practically all political parties. Why the government is so firm to push through the bill? The government claims that it does not have any interest other than the development of the nation. However, one has to look at this phenomenon in the light of various events taking place.

All major political parties in India, irrespective of their ideological and regional differences, refuse to come under RTI (Right To Information Act 2005) which would disclose the sources of their funds. The one exception is the AAP (Am Aadmi Party) which has publicized its financial dealings online. Such refusal of political parties reveals the hidden relationship between economy and polity. However, the general public also has a share in the black money, accumulated by political parties. To vote for a particular party or candidate, people receive benefits either in cash or kind.

Moreover, consumerism defines India's international relations. The current Prime Minister, Narendra Modi had been denied US visa for past 12 years, due to his alleged involvement in the 2002 genocide of Muslims in Gujarat, in which approximately 3000 Muslims were massacred. As soon as he became the PM, he was officially invited to visit US. How can one understand the ethic of the denial as well as the invitation? Can one just overlook economic interests between these two nations?

\section{Consumerism and culture}

Consumerist trend affects cultural values like family life. Joint families are becoming nuclear families mostly because of economic reasons. People want to have just one or two children but to provide them with maximum facilities possible. Children without siblings are forced to spend their leisure time with machines, i.e. TV, computer. Parents leave home quite early and reach home late evening due to professional requirements. Thus children are deprived of parental care. This alienation psychologically affects them. Moreover, being a single child and enjoying almost all facilities, the child gains no experience of living with or accommodating other people. S/he grows up having no idea of the realities of suffering and pain. When one faces some difficulties later on, s/he does not know how to cope with it.

On the whole, consumerist society demands people to make money as plenty as possible. Even to bring up one child both the parents need to work. Here we find an asymmetric relation between income and leisure. The more one works and earns the less one relaxes, because the more one earns the more one spends. So people have very little time with spouse and children. More work brings more money but with more stress. What is then the ultimate purpose of making more money which does not provide a peaceful life?

Furthermore, service sectors have been commercialized. We can see "a steady trend towards the businessification of everything; the model for any human interaction is the financial transaction. So, for example, students are now "customers" rather than, say, "clients." Education is seen by some as primarily an avenue by which to make people good producers and consumers. We even see a range of spiritual traditions being plundered so as to be broken up for the saleable tokens and feelgood factors that they may be able to provide $^{6}$.

\section{CONSUMERISM AS A WAY OF LIFE}

Ideologies do impact our way of life and vice versa. Consumerism too affects our thoughts, values and lifestyles. In understanding the conceptualization of modern values of liberty, freedom and equality, Louis Dumont identifies a reversal of val- 
ues. According to him modern world has reversed the traditional primacy of relations among human persons from the original primacy of relations of men to things ${ }^{7}$. This ideological revolution marks the change of attitudes towards human persons and the natural world. The relationship between human persons has become secondary to the relationship between human persons and material goods ${ }^{8}$. Hence economic interests determine how one should relate to other persons and to the natural environment. This ideological reversal has immensely affected our way of life. Let us consider the phenomenon of status consumption.

\section{Status Consumption}

Consumerism makes us live as if material goods are of more importance than human relations which are defined by material standards. Those who possess less are considered to be of lesser value and accordingly deserve lesser respect. Status then becomes essential in to order to convince the society that "I am somebody." The brand of things one purchases defines one's status in society. The mimetic theory of René Girard, at this juncture, helps us understand this dynamics from an anthropological dimension. According to Girard, human beings are mimetic. By imitation, they imitate one another. They learn things by imitating their neighbours. They learn how and what to desire from their neighbours. Hence their desire becomes mimetic desire $^{9}$. My neighbour teaches me what I should desire. In short, I imitate/desire his/her desire. It explains how people imitate one another in the world of consumerism. Alan Pope looks at this phenomenon from a psychological and Indo-Tibetan Buddhist perspective. "Neurologically speaking," he argues, "humans are wired for all manner of consumption and advertisers-just as they have done in the past with behaviorism and psychoanalysisare exploiting the latest trends in psychology in order to stimulate desire, increase profit, and populate the world with ever more hungry ghosts ${ }^{10}$."
In fact, desire has no limit as such. When one is met another arises. In a corporate culture, it forces people to consume on credit. It is really paradoxical to note that those who earn considerably well live mostly in debts. On the contrary, those who are not caught up in the mimetic cycle of consumption seem to live rather peacefully, even though they earn comparatively less. It is not therefore prosperity that brings happiness and peace. It seems to be something else. We shall return to it in the fourth section.

Status consumption tempts people to spend more on non-essentials than essentials. Those who spend quite a lot on mobile phones, cosmetics, and dresses spend much less on quality food and healthy environment which might lead to health problems. Moreover, this type of consumption makes people invariably debtors, because they cannot afford to purchase all they want within their regular income. This indebtedness creates psychological stress and trauma.

\section{Consumerism and Corruption}

There seems to be a close link between consumerism and corruption. Subha Veerapandian identifies four stages in this regard $^{11}$. First, we begin with consuming basic needs. Then necessary consumption becomes status consumption due to social pressure. In the third stage, such status consumption becomes a habit. In the fourth, it becomes a sickness whereby we become addicted to it. Sivaraksa Sulak also feels that "there is nothing intrinsically wrong in having expectations rise, but it is harmful when people who were formerly happy are given to believe that they cannot do without a particular good ${ }^{12}$."

In third and fourth stages, where status consumption becomes habit and sickness, we look for unethical means to satisfy such consumption drives when we can't meet them via ethical means. Hence it gives way to corrupt practices. E.V. Ramasamy (Periyar) observed that "simplicity is the hallmark of honesty." When one spends more money than one's income, believes Periyar, it is an indication that that wealth had 
come through unethical means. M.K. Gandhi also put it in a slightly different way when he said, "Anyone who possesses more than one's need is a thief." Though these statements sound a little exaggeration, they do have some truth in them, particularly in India where we witness the intimate relationship between the impoverishment of masses and the accumulation of wealth by a few.

\section{CONSUMERISM AS SOCIAL MOVE- MENT}

Consumerism as social movement is viewed positively by business and economics. It is about the empowerment of consumers as citizens, upholding their rights, protecting them from abuses of power, and supplying them with objective information that will help them to make rational choices ${ }^{13}$. From this perspective, we shall reflect on ethical consumption and consumer rights.

\section{Ethical Consumption}

By ethical consumption we envisage an ethical relationship between producers, distributors (suppliers) and consumers. Marketing plays a crucial role in this relationship. The idea of free and fair market suggests as if there exists an equal level playing field for all. While pinpointing the hierarchy of human dignity over technological tools from the Gandhian point of view, Michael Amaladoss unravels the myth of "free market ${ }^{14}$, He argues that "the autonomy of the technological and economic machine is a carefully cultivated myth. The "free market" is not really free. It is controlled politically, with the support of military might when necessary, by the richer nations, helped by such 'international' organizations like the IMF, WB and $\mathrm{WTO}^{15}$." These so-called autonomous structures deprive the states, for instance, from the right to control their own economy and market. What neo-liberal economy and its globalization do is to place all its trust in the success of market ${ }^{16}$. Felix Wilfred underscores the deadly effects of the Structural Adjustment Programmes forced by the globalizing process: "It (the state) is forced to deregulate or lose its con- trol over market and economy which are to be handed over to private players operating internationally. And what is worse, the states are forced to cut subsidies for food and other goods from which the poor benefit. And this reduction in government spending is made in such crucial areas as education, health-care and social welfare $^{17}$."

Making consumers aware of the "autonomous" dynamics of market, ethical consumerism enables them to intentionally purchase products and services that have been manufactured, processed or provided through ethical means, in other words, with minimal harm to or exploitation of humans, animals and/or the natural environment. Ethical consumerism is practised through "positive buying" in that ethical products, for example, those branded "fair trade" are favoured over others ${ }^{18}$.

\section{Consumer Rights}

Abhishek Gupta highlights the need and urgency to empower the consumers in India. He sees consumerism as "a protest of consumers against unfair business practices and business injustices ${ }^{19}$." Particularly in India where a majority of population is illiterate, ignorant and ill informed, we need to fight for the protection of consumers. Gupta articulates how consumer is at the weaker side when compared with producers and sellers, because "the producer is able to manipulate the price quality, size, weight, etc. of the product. He has to depend upon the trade practice of the seller. If the seller indulges in unfair trade practice, then the consumer needs protection against such malpractices, the advance of science and technology enables the manufacturers to produce myriad types of goods ${ }^{20}$."

As we have indicated in the first section of this paper, advertising is a potent device for sales promotion. And it is highly deceptive. Consumer does not know the real quality of the goods advertised. S/he feels confused and needs to be guided and protected. However, the consumer movement in India is confined to metropolitan cities like Bombay, 
Ahmadabad, Hyderabad, etc. We need to take it to the least in the society. Indian consumers need to care about the quality, date of manufacture and expiry, particularly in case of food products and medicines. In this connection, Gupta draws our attention to the The Consumer Protection Act, which empowers consumers to protect their rights as consumers. We also have The Drugs and Magic Remedies (Objectionable Advertisement) Act. It is an equally important piece of consumeroriented legislation, the provisions of which influence the advertising decisions of companies marketing drugs for certain ailments specified in it. It aims to prevent advertisement tending to cause an ignorant and unwary consumer to resort to selfmedication with harmful drugs and appliances. The Act prohibits advertisements making false claims for the drug $^{21}$. However, self-policing is far more effective and superior or advantageous than State-policing in the field of distribution. The business community must also take appropriate steps to regulate its conduct and cultivate self-discipline and selfregulation in the larger national interests ${ }^{22}$.

\section{SOME RELIGIOUS-ETHICAL RES- PONSES}

India is known for religious pluralism and tolerance. Religions do play a role in public life. However, there seems to be a gulf between religious teachings and public behaviour. Religious principles like love and justice do not reflect in socio-economic and political structures of the state. In the context of articulating a Buddhist economics, E. F. Schumacher laments that "the Burmese.... had simply adopted development plans from the West, without pausing to think that a Buddhist way of life would call for Buddhist economics ${ }^{23}$."

Furthermore, certain religious practices exhibit consumerist attitudes. The celebration of religious festivals is closely connected to the market. Be it food, crackers, dresses, decorative cars, lighting the whole village or streets, all of them have commercial overtones. Externals take priority over the inner dimension of religiosity. One hardly finds any difference between politi- cal party gatherings and religious festivals both of which manifest sheer demonstration of money power. That does not mean either that religions do not have potential for change. Despite this ambiguity, religions continue to inspire people. The more modernity tries to push religions into private sphere, all the more powerfully they emerge into public sphere in postmodern era. From this background, we shall see how Buddhism, Hinduism and Christianity respond to the consumerist culture from a religiousethical point of view.

\section{The Buddhist Approach of Dhamma}

The Pali word dhamma refers to the Sanskrit dharma which could be understood as harmony between the human, the divine and the cosmic. Buddhism and its Dhamma is a spiritual, philosophic approach based on acceptance and compassion for all living things. Deep philosophy and deep ecology are philosophic sisters ${ }^{24}$. From this holistic view of Buddhist anthropology, Peter Harvey feels disturbed to conceptualize human persons as consumers. For him, "it implies a false reduction of people into consuming-units. On the other hand, it implies an uncomfortable truth about us: we consume the products of the environment and human transformations of natural resources-and in doing this, are increasingly coming to threaten the world's biosphere, our shared home ${ }^{25}$."

To be liberated from the entanglement of greed, hatred, and delusion, which Buddhism considers the roots of world's problems $^{26}$, one needs to move from pleasure to happiness, and that too the happiness of others. As Harvey understands:

Pleasure is by nature fleeting and tends to focus on "me and mine." Happiness can be a more a pervasive attitude-though it is itself changeable-and be related to more open-hearted and less selfish concerns. However, an appreciation of pleasures when they come along, mindful of their limitations, is fine, as is an ability to enjoy simple pleasures. Moreover, bringing pleasure to others can bring real happiness. Generosity and sharing is certainly a source of happiness, and a 
challenge to a society that prioritizes personal consumption ${ }^{27}$.

From the perspective of Tibetan Buddhism Alan Pope identifies our true nature with transcendent humanism. For him, "Genuine fulfilment arises to the extent that we can put the needs of others before our own. Such altruism is not simply a "random act of kindness." Rather, in Tibetan Buddhist thought it is a pervasive modality of being that we must cultivate in order to recover our true nature ${ }^{28}$." Finally, Nagarjuna insists that only sharing can alleviate misery. "Through using wealth" he argues, "there is happiness here and now; through giving there is happiness in the future; from wasting it without using it or giving it away, there is only misery. How could there be happiness? ${ }^{29 "}$

\section{A Hindu Vision for World-Order: Lokasangraha}

From the Vedic notion of yajña, Francis Xavier D'sa pinpoints the fundamental interconnectedness of all beings. For him yajña refers both to world-process and to world-reality. A world-process is a world that is a process, and only what is part of and promotes the world-process is real. Whatever is not part of and does not promote the world-process is not real ${ }^{30}$. In short, yajña is a world where everything is interconnected, interrelated, and interdependent. ${ }^{31}$ D'sa also observes the etymological unity between Sanskrit sarvam and Latin salvum both of which refer to wholesomeness. From this holistic view, he concludes that "whatever world-order we may dream of or proclaim, it cannot afford to overlook the insight that all reality is a relational reality, that is, if the respective world order is to be built on rock, not on sand....All beings emerge from the one source and therefore are relatives; and so every-thing and every-one is related." 32 This is what the vision of lokasangraha basically advocates, because it seeks the wellbeing of all that exists.

Asian cultures rooted in such transcendental religious experiences do have a counter ideological pattern to the aggressive trend of consumerism. They keep alive a spirit of transcendence as providing a dimension of ultimate meaning to their lives and efforts. Many visitors to Asia, observes Amaladoss, are surprised by the cheerfulness and hospitality of the poor. The reason is, he thinks, the refusal to idolize the secular and attachment to transcendent humanist and spiritual values, which relativizes even their poverty ${ }^{33}$.

The control of needs and desires, according to Asian traditions, is the first step in human search for fulfilment. The goal sought after is the quality of life rather than the quality of things that one might accumulate $^{34}$. This view highlights the hierarchy of spiritual goods over temporal goods. And in the context of a larger community of interrelated beings, duty takes priority over rights. Though rights protect the individual from an authoritarian State, reciprocity in a community is not understood in terms of rights that one demands, but in terms of gifts that one can expect from others who have a duty to offer them $^{35}$.

\section{A Christian Vision for Global Solidarity}

Though Christian traditions are accused of propagating an anthropocentric worldview, they have nevertheless insisted on the human responsibility to protect the natural environment. The question of ecological concern is centred on the moral anthropology of Christian thought. The emphasis has therefore been, on the moral dimension of human behaviour. The way human persons relate to the material universe affects their relationship not only with the natural environment but also the inter-human fellowship on global scale.

Biblical ethics emphasizes sharing rather than buying (Mk 6:35-38). Jesus was invariably critical of the dangers of riches which hinder inter-human and humandivine relationship (Lk 12:15; 18:24-25). Jesus' dining with the poor, his presence among the marginalized (Lk 15:1-2) and his identification with the suffering and dying (Lk 6:17-19) could be seen as a counter culture to the consumerist society of his time in which poverty and sickness 
were seen to be a divine curse and prosperity a blessing.

In recent years the Catholic Church is using the language of solidarity in order to reach out to the poorest of the poor. Biblical anthropology, founded on the sacred dignity and the social nature of the human person, demands a deep sense of global solidarity with the suffering humanity as well as with the natural environment (Gen 1:26-27). The latest encyclical of Pope Francis, Laudato Si' ever forcefully urges the need for solidarity with nature.

Environmental education has broadened its goals. Whereas in the beginning it was mainly centred on scientific information, consciousness-raising and the prevention of environmental risks, it tends now to include a critique of the "myths" of a modernity grounded in a utilitarian mindset (individualism, unlimited progress, competition, consumerism, the unregulated market). It seeks also to restore the various levels of ecological equilibrium, establishing harmony within ourselves, with others, with nature and other living creatures, and with God. Environmental education should facilitate making the leap towards the transcendent which gives ecological ethics its deepest meaning. It needs educators capable of developing an ethics of ecology, and helping people, through effective pedagogy, to grow in solidarity, responsibility and compassionate care (LS 210).

\section{CONCLUSION}

The words economics, ecumenism and ecology have common roots in Greek, i.e. oikos, meaning house. From this common ground Nancy Wright asks, "How is all 6.6 billion of the world's human population to live together in one house, the earth? How are we to arrange our affairs (economics) and our life attitude (spirituality, religion, ecumenism) wisely and well and care for our homeland (house, the Earth)? What does this mean for our political arrangements, governing how we live together in community, whether in the city or in rural areas, in our homeland ${ }^{36}$ ?" Laurie Michaelis seems to propose a reasonable response to these questions when he says, "a minimum level of consumption is a prerequisite for human flourishing but we should aim to develop ideals of the good life that can be achieved without excessive material consumption. If they are to succeed, such ideals will have to resonate with existing values and involve nurturing communities as well as individuals ${ }^{37}$. Inspired by the Buddhist idea of sangha we can create transforming communities.

To facilitate the development of moral communities: groups with shared ethics, based on a vision of the good life. Members of our society do not want to be told how to live, even for their own or others' good, but they are interested in entering a dialogue through which they can work out their choices for themselves. New moral communities might be based on local communities, or on individuals and institutions with shared interests at a national or international level ${ }^{38}$.

\section{CATATAN AKHIR}

1 Alan Aldridge, Consumption (Malden, Mass.: Polity, 2003) 2; cited in Kenneth R. Himes, "Consumerism and Christian Ethics," Theological Studies 68, 1 (2007): 132.

2 Raymond Williams, "Consumer," in Consumer Society in American History: A Reader, ed. Lawrence Glickman (Ithaca, N.Y.: Cornell University, 1999) 17; cited in R. Himes, "Consumerism and Christian Ethics," 133.

3 R. Himes, "Consumerism and Christian Ethics," 133.

4 Amartya Sen, Development as Freedom (Oxford: Oxford U. P., 1999), 13.

5 Ibid., 13-14.

6 Peter Harvey, "Buddhist Reflections on Consumer and Consumerism," Journal of Buddhist Ethics, 3 (2013): 335

7 Louis Dumont, Essays on Individualism: Modern Ideology in Anthropological Perspective (Chicago: The University Press, 1986) 36.

8 Morris Antonysamy, "The Challenge of Caste System in an Age of Globalization: An Anthropological Investigation of Hierarchy and Mimesis," A Dissertation for obtaining the Degree of Doctor of Theology, (Leopold-Franzens-University: Innsbruck, 2013) 64

9 René Girard, I See Satan Fall Like Lightning, trans. James G. Williams (New York: Orbis Books, 2001): 10.

10 Alan Pope, "Modern Materialism: Through the Lens of Indo-Tibetan Buddhism," International Journal of Transpersonal Studies, 30 (1-2) 2011, 173. The iconography of hungry ghost is used as a 
metaphor that symbolizes the ever insatiable craving of human beings for material goods.

11 Subha Veerapandian, "Consumerism and Austerity,"

https://www.youtube.com/watch?v=kNWandOAn Rs (accessed on 10 August 2015).

12 Sivaraksa Sulak, Seeds of Peace: A Buddhist Vision for Renewing Society (Berkeley: Parallax Press, 1992) 30.

13 Alan Aldridge, Consumption, 6.

14 Antonysamy, "The Challenge of Caste System in an Age of Globalization....," 244.

15 Michael Amaladoss, "Globalization and CounterCulture: Liberation Movements in Asia," in Globalization and its victims as seen by its victims, ed. Amaladoss M, 134 (Delhi: ISPCK, 1999).

16 Antonysamy, "The Challenge of Caste System in an Age of Globalization...," 206.

17 Felix Wilfred, Asian Dreams and Christian Hope: At the Dawn of the Millennium (Delhi: ISPCK, 2000) 8 .

18 S. Kamalakannan, "A Study on Ethics of Consumerism in India," International Journal of Management, 3, 3 (2012): 170.

19 Abhishek Gupta, "Consumerism \& Indian Culture," http://www.omicsonline.org/scientificreports/2167-0234-SR-708.pdf (accessed on 3 September 2015).

20 Abhishek Gupta, "Consumerism \& Indian Culture,"

21 Abhishek Gupta, "Consumerism \& Indian Culture,".

22 Abhishek Gupta, "Consumerism \& Indian Culture,"

23 E. F. Schumacher, Small is Beautiful: A Study of Economics as if People Mattered (London: Blond and Briggs, 1973) 48; cited in Harvey, "Buddhist Reflections on Consumer and Consumerism," 344.

24 Daniel H. Henning, A Manual for Buddhism and Deep Ecology

http://www.buddhanet.net/pdf_file/deep_ecology.p df (accessed on 28 August 2015)

25 Harvey, "Buddhist Reflections on Consumer and Consumerism," 335.

26 Harvey, "Buddhist Reflections on Consumer and Consumerism," 335.

27 Harvey, "Buddhist Reflections on Consumer and Consumerism," 338.

28 Pope, "Modern Materialism: Through the Lens of Indo-Tibetan Buddhism,"175.

29 Rāja-parikathā-ratnamāla (of Nāgārjuna), Translated in Nagarjuna and the Seventh Dalai Lama, The Precious Garland and the Song of Four Mindfulnesses (London: George Allen \& Unwin, 1975) 315.

30 Francis Xavier D'sa, “Lokasangraha - The Welfare of the Whole World: A Hindu Vision of a World Order," Jnanadeepa - Pune Journal of Religious Studies 2, 1 (1999) 48.

31 Fritjof Capra, The Turning Point: Science, Society and the Rising Culture (Fontana: Bantam, 1984), 285-87; cited by D'sa, "Lokasangraha: The Welfare of the Whole World...," 49.
32 D'sa, "Lokasangraha: The Welfare of the Whole World...," 49.

33 Amaladoss, "Globalization and Counter-Culture.." 133.

34 Amaladoss, "Globalization and Counter-Culture.."

35 Amaladoss, "Globalization and Counter-Culture.." 134-35.

36 Nancy Wright, "Christianity and Environmental Justice" http://www.mipandl .org/faith_resources/Christianity\%20and\%20Envir onmental\%20Justice.pdf (accessed on 16 August 2015).

37 Laurie Michaelis, Ethics of Consumption, (Oxford: The Oxford Centre for the Environment, Ethics \& Society, 2000) 3.

38 Laurie Michaelis, Ethics of Consumption.

\section{DAFTAR RUJUKAN}

Aldridge, Alan. Consumption. Malden, Mass.: Polity, 2003.

Amaladoss, Michael. "Globalization and Counter-Culture: Liberation Movements in Asia." In Globalization and its victims as seen by its victims. Edited by Amaladoss M. Delhi: ISPCK, 1999.

Antonysamy, Morris. "The Challenge of Caste System in an Age of Globalization: An Anthropological Investigation of Hierarchy and Mimesis," A Dissertation for obtaining the Degree of Doctor of Theology. Innsbruck: Leopold-FranzensUniversity, 2013.

Capra, Fritjof. The Turning Point: Science, Society and the Rising Culture. Fontana: Bantam, 1984.

Dumont, Louis. Essays on Individualism: Modern Ideology in Anthropological Perspective. Chicago: The University Press, 1986.

D'sa, Francis Xavier. "Lokasangraha - The Welfare of the Whole World: A Hindu Vision of a World Order," Jnanadeepa - Pune Journal of Religious Studies 2, 1 (1999): 47-59. 
Girard, René. I See Satan Fall Like Lightning. Translated by James G. Williams. New York: Orbis Books, 2001.

Gupta, Abhishek. "Consumerism \& Indian Culture."

http://www.omicsonline.org/scientificreports/2167-0234-SR-708.pdf

Harvey, Peter. "Buddhist Reflections on Consumer and Consumerism." Journal of Buddhist Ethics, no. 3 (2013): 333-356.

Henning, Daniel H. A Manual for Buddhism and Deep Ecology http://www.buddhanet.net/pdf_file/de ep_ecology.pdf

Himes, Kenneth R. "Consumerism and Christian Ethics." Theological Studies 68, no. 1 (2007): 132-153.

Kamalakannan, S. "A Study on Ethics of Consumerism in India," International Journal of Management. 3, 3 (2012): 169-174.

Michaelis, Laurie. Ethics of Consumption. Oxford: The Oxford Centre for the Environment, Ethics \& Society, 2000.

Pope, Alan. "Modern Materialism: Through the Lens of Indo-Tibetan Buddhism." International Journal of Transpersonal Studies, 30, nos.1\&2, (2011): 171-177.
Raja-parikatha-ratnamala (of Nagarjuna). Translated in Nagarjuna and the Seventh Dalai Lama, The Precious Garland and the Song of Four Mindfulnesses. London: George Allen \& Unwin, 1975.

Schumacher, E. F. Small is Beautiful: A Study of Economics as if People Mattered. London: Blond and Briggs, 1973.

Sen, Amartya. Development as Freedom. Oxford: Oxford U. P., 1999.

Sulak, Sivaraksa. Seeds of Peace: A Buddhist Vision for Renewing Society. Berkeley: Parallax Press, 1992.

Veerapandian, Subha. "Consumerism and Austerity."

https://www.youtube.com/watch? $\mathrm{v}=\mathrm{k}$ NWandOAnRs

Wilfred, Felix. Asian Dreams and Christian Hope: At the Dawn of the Millennium. Delhi: ISPCK, 2000.

Wright, Nancy. "Christianity and Environmental Justice." http://www.mipandl.org/faith_resourc es/Christianity\%20and\%20Environme ntal\%20Justice.pdf 